Abstracta Iranica Iranica

Revue bibliographique pour le domaine irano-aryen

Volume 29 | 2008

Comptes rendus des publications de 2006

\title{
«Les Grecs sous les drapeaux des Arsacides », Parthica, 7, 2005, pp. 65-70.
}

\section{Rémy Boucharlat}

\section{(2) OpenEdition}

10 Journals

\section{Édition électronique}

URL : http://journals.openedition.org/abstractairanica/26652

DOI : 10.4000/abstractairanica.26652

ISSN : 1961-960X

Éditeur :

CNRS (UMR 7528 Mondes iraniens et indiens), Éditions de l'IFRI

Édition imprimée

Date de publication : 15 mai 2008

ISSN : 0240-8910

Référence électronique

Rémy Boucharlat, « "Les Grecs sous les drapeaux des Arsacides », Parthica, 7, 2005, pp. 65-70. », Abstracta Iranica [En ligne], Volume 29 | 2008, document 106, mis en ligne le 15 septembre 2008, consulté le 26 septembre 2020. URL : http://journals.openedition.org/abstractairanica/26652 ; DOI : https://doi.org/10.4000/abstractairanica.26652

Ce document a été généré automatiquement le 26 septembre 2020.

Tous droits réservés 


\title{
« Les Grecs sous les drapeaux des Arsacides ", Parthica, 7, 2005, pp. 65-70.
}

\author{
Rémy Boucharlat
}

Lors de la conquête de l'empire séleucide, la politique de Mithridate I ${ }^{\mathrm{er}}$ a été d'obtenir la collaboration des Grecs, en leur accordant des privilèges, et en accordant sa confiance, aussi bien dans le domaine militaire, par des commandements, que dans le domaine de l'administration. Les communautés grecques ou hellénisées pouvaient trouver intérêt à cette collaboration, l'union face aux dangers extérieurs, comme les Arabes du désert. Par quelques exemples, rapidement présentés, l'A. montre que cette politique n'a pas réussi ; pourtant Mithridate n'abolira pas les privilèges qu'il avait accordés aux Grecs lors de la conquête.

\section{INDEX}

Thèmes : 3.2.3. Séleucides, Parthes et Sassanides

\section{AUTEURS}

RÉMY BOUCHARLAT

CNRS - Lyon 